\title{
The Influence of Liberty Concepts on the Legal Classification of Constitutions and Constitutional Governments
}

\author{
Alireza Asadpour Tehrani ${ }^{1} \&$ Masoud Raie Dahaghi ${ }^{1}$ \\ ${ }^{1}$ Department of Law, Najafabad Branch, Islamic Azad University, Najafabad, Iran \\ Correspondence: Alireza Asadpour Tehrani, Department of Law, Najafabad Branch, Islamic Azad University, \\ Najafabad, Iran. E-mail: alirezatehranilaw@gmail.com
}

Received: May 24, 2017

doi:10.5539/jpl.v10n4p139
Accepted: June 10, $2017 \quad$ Online Published: August 30, 2017

URL: https://doi.org/10.5539/jpl.v10n4p139

\begin{abstract}
Due to global developments in constitutional law and especially the importance of principles of republicanism, the sovereignty of the people and the protection of individual rights and public liberties as the foundations of constitutionalism and constitutional government, it seems that a new category of constitution that is consistent with the principles and foundations of constitutionalism and the constitution should be provided. Therefore, the classical categories of constitutions are briefly introduced and then their unlawful aspects will be criticized and then, new categories of constitutions are introduced and described. This classification is based on the assumption that republic governments can be constitutionality and with a focus on the protection of liberty can use its power without being required to comply with liberty in its liberal concept. So as constitutions can be divided into two types of liberalism and republicanism, governments can be classified into two types of Republicanism and liberalism too. Since the classic categories have acted based on inductive method, therefore, this method has been used to criticize and propose alternatives.
\end{abstract}

Keywords: constitution, constitutionalism, constitutional government, liberty, liberalism, republicanism

\section{Introduction}

Since the French Revolution and the establishment of the Republic, the constitution and compliance with the principles and rules contained therein was one of the main challenges in the subject of political power. With the development of the Republic and Constitutionalism, the subject was that what relationship can and should be between the content of these two concepts? In addition, how should be the government restrictions to the constitution, by the aim of protecting individual rights and public liberties and the sovereignty of the people, in order to create a stable political power and on the other hand, not to have an adverse effect on social relationships and private life of people? These are practical concerns that seem that in theoretical debate, less attention has been paid to it. One of the most important examples is various theoretical categories of constitutions, without any attention to the relationship between these categories with types of governments. In addition, these categories have been proposed at the times that constitution as a legal written document was not dominant and influential in government policies. Hence, these categories in a highly abstract and useless way are practical and realistic. It is therefore necessary that while presenting a new category of constitutions, their relationship with liberties and government are measured and examined.

Categories with inductive reasoning style are presented. Therefore, to analyze, review, and criticize them and especially offer alternative proposals, inductive method should be used.

\section{Key Words Definitions}

\subsection{Constitution}

Constitution is a fundamental or basic codified legal document which contains organized rights and obligations of government and citizens. This organized form is the result of the sovereignty of nations and the rights and fundamental liberties.

\subsection{Constitutionalism and Constitutional Government}

Constitutionalism means reduction and justifying all acts of political institutions based on Constitution principles and rules. Thus, according to the definition of the Constitution, Republican, sovereignty of the nation and 
individual rights and public liberties are known as foundations of Constitutionalism. Thus, constitutional government is a kind of republic that its action, reduction and its justification of political power is on the basis of compliance with the Constitution and its interpretation is based on the protection of the nation's sovereignty and individual rights and freedoms of the public.

\subsection{Classic Categories of Constitutions and Review}

Basically, the emergence and development of any knowledge are accompanied by the concepts. Creating concepts and their specific definition in every knowledge, facilitates training and understanding that knowledge, but what makes easier and deepen the learning and understanding, is organizing and categorizing concepts. In all sciences, the purpose of concept classification is creating an overall process to categorize topics. Through this process, ideas and objectives are known and distinct and can be understood more precise and clearer. Constitutions have been classified for different reasons. The most common classifications are:

1) written (codified) constitution and unwritten (uncodified, customary) constitution

2) Rigid constitution and flexible constitution

3) Homogeneous and mixed constitution.

4) Authoritative and democratic constitution (Ghazi, 2010, pp: 96 - 100).

Albert Venn Dicey (1835-1922) is one of the first English experts that has written books in the field of Constitution in UK, and in it, according to features of government, power and political order of the day in England, to prove that England, as well as other leading states has Constitution, has offered a particular Category of Constitution. For the validity of this argument, note to the examples for each of the above dual divisions.

Codified and non-codified constitution: The vast majority of countries have a written constitution except England that has non-written constitution.

Rigid and flexible constitution: "When Constitution can be revised in the same way that ordinary laws are (by the same organization or the same procedure), it is flexible [...]

Rigid constitution is a law that its revision ceremony is done by special parliamentary or with other special procedures that is different from revision procedures of common law" (Ibid: 98).

For the first time, Dicey suggests this category. It seems that his main reason for classification of constitutions is to prove that England have political order and thus have the constitution. However, their constitution is different with other countries (Dicey, 1889, pp: 122-124, 169, and 428).

Currently, the majority of countries for amending their constitution have special, distinct and different procedures from other laws. England is an exception in this regard and its non-written constitution reform process is similar to its other laws.

Democratic and non-democratic (authoritative) constitution: Due to the development of the idea of democratic governance, now even countries that do not observe a minimum of democratic norms in practice, pass their constitution by democratic coatings like referendum and plebiscite and other similar cases. From three hundred years ago, England is the only government that non-written documents of its constitution have been deployed by granting to the peasant by the king. It seems that by the practical expansion of constitutionalism (In particular, the principle of supremacy of the Constitution over other laws) and the importance of the Republic as the desirable model of governance at the global level, these categories of constitutions are not legally useful. All these classifications do not pay attention to the principles and foundations of constitutional law and often have been presented under the influence of political approaches and ideas. In all discussions and subjects related to constitutionalism, citing these classifications is not useful for advancing a legal argument and even sometimes it can disrupt discussion expansion and entry of newer theories in constitutional law. It seems that the proposers of these categories have shared thoughts:

England as the founder of liberalism should be separated (not necessarily opposition) from other governments so that the traditions of political liberalism will be protected.

However, perhaps in the past, the induction that was offered by Dicey and others about the classification of constitutions was complete induction, because it was based on the review of the constitution of their own time and with the aim of proving the existence of a constitution for England so this categorization was essential. But this purpose from the beginning firstly has cause cited generalization to be inaccurate and inconsistent. This means that no country after England resorted to Flexible Constitution. Secondly, given that most countries in the past, except a few of them, were free from any document (including written or non-written) as a result, evidence 
of inductive generalization were not sufficient or conventional samples.

\subsection{An Overview of the Concept of Political Liberalism}

Liberalism is a theory that significantly many books have been published about it and its most important theorists. So, it seems that in this article, there is no need to explain and analyze the political, economic, social aspects of this theory completely from the earliest times to the present. So in the discussion of political liberalism, only the topics will be discussed that lead to the advance a legal argument about the reasons for offering a new and legal classification from a type of constitutions.

According to the history of liberalism, it seems that political Liberalism is a phenomenon that has been started from the culture and tradition of analytic philosophy but has also attracted the attention of continental philosophy. For this reason, some believe that the French Revolution, in particular, the word great that is attributed to it is due to the influence of liberalism in the revolutionary thoughts and the Declaration of Rights of Man and Citizen, is nothing more than explaining the principles of liberalism.

Liberalism in Europe was the beginning of a new era that was emerged during the fifteenth and sixteenth centuries $\mathrm{AD}$, when the new order of life was replaced by feudalism and during the seventeenth and eighteenth centuries, entered to North America by European immigrants. In Politics, Liberalism is a full range of ideas and theories about the structure and duties of government. Liberalism literally is the meaning of liberty. Thus, Liberalism as a term in political thought, while has a lot of meanings, usually relates to the concept of liberty, especially civil and political liberties. Maybe it can say that the debate about personal liberty is the most important shared political goal by all schools of liberalism. In this respect, we can conclude that this term refers to the political views or policies of those that their basic purpose in the Government is obtaining and maintaining a certain amount of individual liberty from the shackles of government control or direction or other factors which may be undesirable for individual will. Political liberalism has special attention to liberty as individual rights.

\subsection{The Legal Concept of Liberalism (Legal Liberalism)}

Liberalism as a political philosophy gives absolute priority to individual rights and liberty derived from individual rights. Political Liberalism demands guarantee for a basic domain of freedom, including freedom of conscience, expression and association and emphasized that the government should not intervene in these matters unless for supporting people. Liberalism has a special emphasis on individual rights as a kind of freedom and introduces freedom derived from human individuality both in the public sphere and in the privacy. As a result, in terms of political philosophy, liberalism pays attention to negative concept of liberty. It seems that we can explain liberalism as a concept of constitutional law, in a way that generally people are not subject to authoritarian rule, but in their lives: First, they have privacy; secondly, they are under protection of the law. Thirdly, in public affairs, they have the right to contribute in the affairs of governance through free and fair elections and fourthly, they can monitor their candidates. So the legal foundations of liberalism can be described in this way:

a) Protecting individual freedoms of citizens, as an individual right.

b) Limiting the authority of government on individual freedoms, as the right to protection of privacy.

In short, it seems that legal philosophy of liberalism is that the government has no right to invade the liberty of citizens. The ban is the source of individual liberty as civil liberties.

\subsection{The Relationship between Negative and Positive Liberty with Legal Liberalism}

Systematically, discussion of liberty or freedom and classifying it into two positive and negative was introduced for the first time by Isaiah Berlin.

Berlin, first defines liberty through its opposition concept: "to coerce a man means depriving them from freedom" (Berlin, 2002, p: 168). According to this definition, he has extracted two basic meanings for freedom: Negative liberty and positive liberty. He believes that the simplest definition of negative liberty is in this way: "the area within which the subject - a person or group of persons - is or should be left to do or be what he is able to do or be, without interference by other persons "(Ibid. 169). Berlin, defines negative liberty as others intentional non-interference and for outlining the scope and framing of this type of freedom he writes: Coercion implies the deliberate interference of other human beings within the area in which I could otherwise act. You lack political liberty or freedom only if you are prevented from attaining a goal by human beings. (Ibid) In short, Berlin, introduces positive liberty as self-mastery. He writes that in this concept, freedom means that "I wish to be somebody, not nobody" (Ibid: 178).

He writes in the description of this statement: "a doer - deciding, not being decided for, self-directed and not 
acted upon by external nature or by other men as if I were a thing, or an animal, or a slave incapable of playing a human role, that is, of conceiving goals and policies of my own and realizing them." (Ibid: 178)

Berlin criticized the positive liberty. He said: "The perils of using organic metaphors to justify the coercion of some men by others in order to raise them to a 'higher' level of freedom have often been pointed out." (Ibid: 179)

\subsection{Gative Liberty and Liberalism}

According to Berlin-based division of Liberty and Montesquieu classification of forms of government (The Spirit of the Laws, Book II, Chapter I) Philippe Petit introduced "Republicanism". He believes that Berlin has created a more attractive view for negative liberty and has shown positive liberty much more ominous (Pettit, 2002, p: 18). For this reason, liberalism has taken place republicanism (Ibid: 12).

Pettit believes that constitutionalism is a strategy through which republic-oriented government is as much as possible non-manipulable. By Constitutionalism, government can create the maximum resistance against arbitrary or maybe collective basis (Ibid: 173).

So if we want to express the results of this discussion within the framework of constitutional law, we can say that from the perspective of the Constitution, negative freedom (freedom of...), turns the collection of freedoms to individual rights and positive freedom (freedom for...), turns the collection of freedoms to individual rights and public freedom. So attitude of these two theories about limitation of government power is different.

As was emphasized before: "The essence of liberalism is separation of government and community areas, and limitations on state power against the rights of the individual in society" (Bashiriyeh, 2010, p: 11).

The essential difference between liberalism and Republicanism starts from "droit public économique" debates. Liberalism believes that economic freedom is the condition for the realization of other freedoms including political freedoms. From this perspective, when political freedom can be achieved that the capitalistic system is created. Thus, liberalism is close to capitalism economically" (Ibid: 13).

Although it can be said "from a liberal perspective, individual has priority over the community and individual interest has priority over the interest of the community" (Ibid: 14). But, in practice, this interest and priorities have become the interests and priorities of the capitalistic class. The result is that the capitalistic class first appears in the form of an economic oligarchy and then influences the political oligarchy or enter to the political oligarchy and become an economic or political oligarchy.

Although in liberalism "person and his objects is original and social institutions, including the government are a mean for providing them"(Ibid) but government supports those people and their objects that have more financial benefits for it.

In short, legal philosophy of liberalism is that the only responsibility of government is to protect individual rights for peoples. In this case, we conclude that liberalism focuses on political and individual aspect of freedoms and the principle of politics in society.

Based on the principle of politics in society, freedom means the obligation of the government not to interfere in the life and property of persons.

Professor Elizabeth Zoller believes that the most important legal aspects of liberalism are its definition from the public interest. "Authors who support liberalism regard the public interest as the total aggregation of private interests. Liberal theory is characterized by the belief that the public interest can never be different from the sum of private interests; the public good is identified with the maximum aggregation of individual preferences. It is inseparable from the satisfaction of all individual interests. The liberal theory of the public interest aims at ensuring the greatest protection to individual interests; it therefore gives priority to liberty and considers that "if someone has a right to something, then it is wrong for the government to deny it to him even though it would be in the general interest to do so" (Zoller, 2008, p: 13).

It seems that the interpretation of Zoller about the legal liberalism is that she believes that when liberalism gives credit to the public benefit that private interests are identified and confirmed one by one, and then it can be created (not necessarily confirming the public interest). For this reason, she analyzes: "Liberalism claims, in substance, that a measure meets the requirements of the public interest if it satisfies all private interests. Under an economic analysis of the law, in order to qualify as a measure of public interest, a law or a regulation must meet the criterion of the so-called the Pareto efficiency or Pareto optimum. A measure is said to meet this test if it makes someone better off without making someone else worse off, or, to put it differently, if it improves someone's situation without injuring anyone else. Inasmuch as, in reality, this test can be met only in exceptional circumstances, liberalism is likely to consider measures of alleged public interest - in other words, the 
laws - with a skeptical, if not hostile, eye. Liberals tend to doubt that laws can be made so as to satisfy the criteria of a true public interest. Thus, they eventually come to associate less law with the citizens' well-being. Much inspired by the economic theories of law, today's liberalism opposes governmental power on the ground that it is useless except to ensure public peace. They defend minimalist approaches to legislation within the general framework of an economic theory of law" (Ibid: 13).

It seems that Zoller in her legal analysis of liberalism, in addition to the approval of former reviews, criticizes the extensive use of economic analysis of law by liberalism. This use is so far advanced that in practice; legal rules, including public order can be measurable by private interest criteria. The result of such a measure in legislation is that, first of all the rules of laws (public and private law) are considered complementary rules (not mandatory rules). Secondly, it is axiomatic that the rules of public law are an absolute subordinate of private interests. As a result, wherever there is a conflict between public law and private interests, those rules should be interpreted in order to facilitate the flow of private interest.

Views of Isaiah Berlin are one of those theories that could be applicable for the principle of "less law, more benefits for citizens". In summing up the comments of classical English political philosopher, he concludes that what these scholars agreed is that the sphere of action of human freedom should be limited by law (Berlin, 2002, p: 170). But he immediately adds that these scholars believe that we need a certain minimum area of personal freedom that should never be violated. Then he concludes that the border should be drawn between the sphere of private life and public authority. He believes: "But both sides agreed that some portion of human existence must remain independent of the sphere of social control" (Ibid: 171 -173).

It seems that from the perspective of Zoller, Liberalism does not have the ability to establish "état de droit". On the other hand, communitarism and collectivism are not working in practice. She proposes "Republicanism": "For those who defend republicanism, the public interest is not reducible to an aggregation of private interests. Instead, the public interest is the aggregation of the private interests that members of the society share in common, or, to be more precise, that members of a society decide to regard as common in the social contract that forms the republican compact" (Ibid: 13).

She added: "In this sense, the republican theory of the public interest is the opposite of the liberal theory. It does not question for a moment the existence of a public interest in itself; it believes in the existence of a public thing, a res publica, autonomous and independent from private things. It defends the idea of a public interest as distinct from the total aggregation of private interests. It aims at ensuring the greatest protection for common interests, even, if necessary, against private interests, because it operates on the premise laid down by Jean-Jacques Rousseau: "The common element in these different interests is what forms the social tie; and, were there no point of agreement between them all, no society could exist." The public interest is the sum of the interests held in common by society; it means "common security, common liberty," or, as Sieyes's put it in one word, "the res publica (chose publique)" (Ibid; $13 \& 14$ ).

American-Austrian economist Joseph Alois Schumpeter in his book "Capitalism, Socialism and Democracy" presents this critical to the public interest that there is no general attitude about the concept of public interest that all people can agree with it or create it by agreement on the power of the rational argument. In the first place, this is not due to this fact that some people can want something other than the public interest, but the basic fact is that for individuals and for various groups, public interest has meaning in different areas (Schumpeter, 2003, p: 251).

\subsection{The Rise of Republicanism}

Zoller in response to this analysis argues: "Republicanism believes in the public good and seeks to attain it. For a republican, the measure of public interest is that it satisfies the interests put in common in the social contract. In terms of economic analysis, a measure of public interest, for the republicans, is the Kaldor-Hicks concept of wealth maximization. Under that approach, a measure is said to be efficient if, and only if, those who benefit from the policy benefit sufficiently so as to compensate those who lose. The winners in fact don't need to compensate the losers, but it must be possible. This condition, which effectively transforms the public interest into the general interest - "general" because it satisfies both public and private interests - may actually be easily realized in practice. Capitalizing on the optimistic prospects opened by this opportunity, republican authors attach much value to sovereignty as a principle of political action, and they give preference to the statute as an instrument for the public good. They often, but not always, defend maximal approaches to legislation in pursuance of a political theory of the statute" (Zoller, 2008, p: 14 - 15).

Therefore, it can be said, two legal principles of Republicanism are limiting the power of government and adjustment of individual rights and public liberties through the separation of public and private spheres from each other in social life. 
Due to this, it seems that in constitutional law approach, liberalism and Republicanism are common in two ideas:

a) Belief and protection of individual rights and public liberties of citizens,

b) Limitation on government power.

But what separates these two theories is their attitude about liberty. In terms of political philosophy, Liberalism focuses on the concept of negative liberty and Republicanism focuses on the concept of positive liberty.

Republicanism believes that the government should not be dependent undisputedly on the capitalist class, but should spread democracy through the growth and formation of middle-class forces in civil society and thus reduces the dependence of government to capitalistic class.

Legal philosophy of Republicanism believes that the government has full responsibility to society in order to provide equality. ${ }^{1}$ Therefore, Republicanism focuses on the legal aspect of freedoms and the principle of law in society. Based on the principle of law in society, freedom means the right to choose and the right to use natural rights and therefore the government is responsible to be accountable for its decisions. This responsibility based on the principle of constitutional judicial supervision. Some of the most important responsibilities that government has obtained through the law in society and the use of positive freedom are as follows: to support public education, to guarantee job security, to protect the health and public health (Bellamy, 2007, p: 16).

\section{Conclusion}

According to these descriptions, we can conclude from the perspective of Republicanism that first; freedom or liberty means the absence of domination. Secondly, democratic participation is valuable, but individual or personal participation is not a fundamental criteria of democratic participation. Thirdly, public interests, in principle are independent from private interests and are not subordinate or result of private interests.

It seems that to precisely understand the legal Constitutionalism with regard to the individual rights and public liberties position in interpreting the Constitution, a new classification of constitutions must be provided:

1) Liberalistic constitutions,

2) Republicistic constitutions.

Consequently, due to the content of constitutions, governments can be divided into two categories:

1) Liberal governments,

2) Republic governments.

In this sense Liberal government is defined as a government that its constitution has been developed on the basis of negative freedom and Republicanism government is a government that its constitution has been developed based on positive freedom and separation of rights from freedoms. So that in the republicistic government, we should talk about separation of individual rights from public freedoms because is not equal to freedom. The right relates to individuality of man and their private sphere and privacy. But freedom is linked to the public sphere and their social relations.

It should be noted that the aim of this division is not to conflict Republicanism with liberalism. So from this perspective, Republicanism is not the antithesis of liberalism, but it is its alternative. Because if Republicanism was the antithesis of liberalism, it should have been different in substance. While it is not true. It can be said that the essence or foundation or essential concept of Republicanism like liberalism is separation of government and society fields and limiting the power of government and setting freedoms of citizens. For this reason, it seems that although from the perspective of political philosophy, liberalism can be considered a thesis, but it is not possible to confirm that Republicanism is antithesis. Because Republicanism is a result of synthesis between thesis of liberalism and the antithesis of "communitarianism".

Communitarianism is antagonistic with liberalism because it criticizes the modern liberal political thought. Communitarians emphasize on social context contrast effect and individuals self-conceptions. Now it is claimed that liberalism pays attention to atomized individual artificially and on the other hand, incomprehensibly does not consider the person apart from its social surroundings (McLean, 1996, p: 91).

Although the individual rights strengthen and support the idea of absolute right orientation and public freedoms supports the idea of task-oriented thought, from juxtaposing these two concepts, a sensible balance can be created between right orientation and task orientation. Hence it can be concluded that the most important

\footnotetext{
${ }^{1}$ My meaning about the so-called full responsibility is the general concept of responsibility in law which includes civil liability, criminal liability, administrative liability and constitutional liability of government.
} 
distinguishing aspect of legal Constitutionalism and political Constitutionalism is the balance between individual rights and public freedoms. For the same reason, between the liberal constitution and the republicistic constitution, it is republicistic constitution that can keep legalism of right Constitutionalism balanced and protect and develop it. As the liberal constitution only considers individual aspect of rights, is compatible with political Constitutionalism.

\section{References}

Bashiriyeh, H. (2010). A history of Political thought in twentieth century (Liberal and Conservative Thought). Tehran, Nashr-e-Nay (in Persian).

Bellamy, R. (2007). Political constitutionalism: A republican defence of the constitutionality of democracy. New York, Cambridge University Press. https://doi.org/10.1017/CBO9780511490187

Berlin, I. (2002). Liberty. In H. Hardy (Ed.), New York, Oxford University Press.

Dicey, A. V. (1889). Introduction to the Study of the Law of the Constitution. New York, Macmillan and Co. Ltd.

Ghazi, A. (2010). Constitutional Law and Political Institutions. Tehran, Mizan (in Persian).

McLean, I. (1996). The Concise Oxford of Politics. Oxford, Oxford University Press.

Pettit, P. (2002). Republicanism: A theory of freedom and government. New York, Oxford University Press.

Schumpeter, J. (2003). Capitalism, Socialism \& Democracy. New York, Routledge.

Zoller, E. (2008). Introduction to Public Law (a comparative study). Leiden, Martinus Nijhoff Publishers. https://doi.org/10.1163/ej.9789004161474.i-290

\section{Copyrights}

Copyright for this article is retained by the author(s), with first publication rights granted to the journal.

This is an open-access article distributed under the terms and conditions of the Creative Commons Attribution license (http://creativecommons.org/licenses/by/4.0/). 